PEDAGÓGUSKÉPZÉS, 10-11 (39-40), 2012-2013. 237-238.

\title{
PEDAGÓGUS-TOVÁBBKÉPZÉS RÖVIDNADRÁGBAN, AVAGY HAZATÉRTÜNK A STAFÉTA-TÁBORBÓL
}

\author{
TRENCSÉNYI LÁSZLÓ \\ az Eötvös Loránd Tudományegyetem Pedagógiai és Pszichológiai Karának \\ egyetemi docense \\ trencsenyi.laszlo@ppk.elte.hu
}

11. alkalommal került sor a Magyar Pedagógiai Társaság Staféta-táborára. Ezúttal Győrben a NYME Apáczai Kara gondos házigazdasága mellett. A hagyományosan június utolsó hétvégéjén sorra kerülő szakmai találkozók célja, tartalma és formája a különböző pedagógus-nemzedékek és a különböző pedagógiai szakmák képviselőinek kötetlen eszmecseréje. Így volt ez Győrben is, ahol a tagozat- és hagyományalapító karizmatikus személyiség, Kovátsné Németh Mária méltó növendékekre és utódokra talált. A Kövesdi Viktória vezette „csapat” gazdag programot biztosított, lehetővé tette a legifjabbak részvételét is, $\mathrm{s}$ betekintést engedett egy sajátos úton járó mühely világába.

A tábor programját az MPT éves ,akciója” diktálta, a „Mire való az iskola?” vitára feltett izgalmas kérdése. E kérdés megválaszolását szolgálta a bevezető játék, ahol dramatikus eszközökkel idéztük a különböző koroknak iskola iránti elvárásait, illetve a csoportok megfogalmazták - tárgyak segítségével - saját iskolaképüket. E kérdésre kereste a választ Benedek András professzor, az MPT elnöke „Párbeszéd a konszenzusért" címü, rendszert és stratégiát kereső, igénylő előadásában, gyakorlatias választ kísérelt meg Széles Imre, a megyei pedagógiai intézet igazgatója.

Eredeti helyszínen, a ravazdi Erdei Iskolában és környékén ismerkedhettek az ország minden tájáról érkezett résztvevők az erdőpedagógia, a környezeti nevelés válaszaival, kihívásaival Orbán Tibor erdészet-igazgató, Kövecsesné Gösi Viktória és Lampert Dávid föiskolai oktatók segítségével. A tábor lakói felkeresték a magyarországi iskola közeli bölcsőhelyét és mai fellegvárát, Pannonhalmát is.

Poór Zoltán indított diskurzust a ,jó pedagógusról”, majd ,jó gyakorlatokkal” a város kiváló intézményei mutatkoztak be. Csenger Lajosné a gyakorló iskolát, Somogyi Angéla a nevelési tanácsadás előtt álló feladatokat, Papp Gyöngyi a hejökeresztúri mintát követő, az etnikai kihívásokat megoldani vállalkozó Kossuth Lajos Általános Iskolát, Józsa Tamás a „pedagógiai remekmüvetű”, a Hild Szakközépiskolát mutatta be (ahol egyebek közt „szakmai és emberi gyakorlatnak” nevezik a diákok terepmunkáját). Kraiciné Szokoly Mária a tudástársadalom összefüggéseiben helyezte el és igenelte az életen át tartó tanulás életen át tartó eszméjét, Farkas Annamária a kisebbek, az óvodások körében gyakorolt fejlesztő módszereit mutatta be. 
A program várakozással telített légkörében hárman, Fábry Béla, Nahalka István, Trencsényi László, akik egyben a Hálózat a Tanszabadságért, az Agóra Közoktatási Kerekasztal aktivistái is kezdeményeztek tartalmas párbeszédet - a konszenzusért az MPT közremüködésével készült, a foglalkoztathatóságot, a méltányosságot és az alkalmazkodóképességet szolgáló közoktatási rendszer kívánatos jellemzőiről. A beszélgetés során szó esett arról, félelem. apátia vagy éppen a 2010 óta bekövetkezett változások a fö oka a pedagógustársadalom „csendjének”, szó esett a centralizálás és a demokratikus önkormányzatiság köré szerveződő két markáns társadalom- és iskolaképről, a helytállás, a romlás, a káosz, a remény és reménytelenség egymás mellett jellemezték a megszólalások főbb szólamait.

A táborozók hazatértek, a párbeszéd folytatódik. Az MPT folytatni kívánja a párbeszédet - a konszenzusért. 